\title{
Transcription Factor 7-Like 2
}

National Cancer Institute

\section{Source}

National Cancer Institute. Transcription Factor 7-Like 2. NCI Thesaurus. Code C30080.

Transcription factor 7-like 2 (619 aa, $\sim 68 \mathrm{kDa}$ ) is encoded by the human TCF7L2 gene.

This protein is involved in the positive regulation of transcription, cell cycle arrest, apoptosis regulation, cell and tissue differentiation and signal transduction. 